\title{
Influence of pH and Fluoride Species on the Corrosion Behavior of Ti-xNb-13Zr Alloys in Ringer's Solution
}

\author{
A. Robin and O. A. S. Carvalho \\ Departamento de Engenharia de Materiais, Escola de Engenharia de Lorena, Universidade de São Paulo, \\ 12600000 Lorena, SP, Brazil \\ Correspondence should be addressed to A. Robin; alain@demar.eel.usp.br
}

Received 24 May 2013; Accepted 5 October 2013

Academic Editor: Luigi Nicolais

Copyright (C) 2013 A. Robin and O. A. S. Carvalho. This is an open access article distributed under the Creative Commons Attribution License, which permits unrestricted use, distribution, and reproduction in any medium, provided the original work is properly cited.

$\mathrm{Ti}-\mathrm{Nb}-\mathrm{Zr}$ alloys are interesting materials for implant applications due to the atoxic character of the $\mathrm{Nb}$ and $\mathrm{Zr}$ alloying elements and to their low elastic modulus when compared to CP-Ti. In this work, the corrosion behaviour of CP-Ti, Ti-5Nb-13Zr, Ti-13Nb-13Zr, and Ti-20Nb-13Zr alloys was investigated in Ringer's solution of $\mathrm{pH}$ 2, 5, and 7.5 without fluorides and containing $1000 \mathrm{ppm} \mathrm{F}$ at $37^{\circ} \mathrm{C}$, through open-circuit potential measurements, potentiodynamic polarization, and electrochemical impedance spectroscopy. The four materials showed a passive behavior in Ringer's solution without fluorides for $\mathrm{pH}$ ranging from 2 to 7.5 and in Ringer's solution of pH 5 and 7.5 containing 1000 ppm F but presented an active behavior in Ringer's solution of pH 2 containing fluorides. The corrosion resistance of all materials in Ringer's solution decreases with both decrease of $\mathrm{pH}$ and addition of fluorides. Ti- $13 \mathrm{Nb}-$ $13 \mathrm{Zr}$ alloy is a little more corrosion resistant than the Ti-5Nb-13Zr and Ti-20Nb-13Zr alloys and, in most conditions, the Ti-Nb-Zr alloys present higher corrosion resistance than CP-Ti.

\section{Introduction}

Commercially pure $\mathrm{Ti}(\mathrm{CP}-\mathrm{Ti})$ is widely used in restorative surgery as dental and orthopedic implants, due to its high corrosion resistance in physiological media and biocompatibility [1]. Nevertheless, some studies showed that titanium release in the organism can lead from local discoloration of tissue to serious inflammatory reactions $[2,3]$. Moreover, the Young modulus of grades 1 to $4 \mathrm{CP}$-Ti (nearly $100 \mathrm{GPa}$ ) is higher than that of bone ( $30 \mathrm{GPa})$. Due to this difference in rigidity, there is a poor load sharing between the bone and the implant and bone resorption may occur. These negative aspects of CPTi led to the development of more corrosion-resistant, more biocompatible, and more wear-resistant titanium alloys with better biomechanical compatibility.

Among these materials, Ti-Nb-Zr ternary alloys are promising since they present a lower Young's modulus (60$90 \mathrm{GPa}$ ) when compared to CP-Ti. The Ti-13Nb-13Zr alloy was the most studied material of this family [4-20]. It was shown to be passive in simulated physiological solutions, such as Ringer's solution $[4,10,12,16]$, Hank solutions [8, 13-15], artificial saliva [9], and phosphate-buffered saline solution (PBS) [5-7], but active in hydrochloric acid solutions [4]. The corrosion resistance of the Ti-13Nb-13Zr alloy was generally slightly higher than or equal to that of $\mathrm{Ti}$ in both saline and acid solutions $[4,8,14,15]$. The microstructure of the Ti-13Nb-13Zr alloy which is dependent on both heat and mechanical treatments [21] affects its corrosion resistance $[4,10]$. Few works are available on the corrosion behavior of other Ti-Nb-Zr ternary alloys $[8,16,22]$. The Ti- $5 \mathrm{Nb}-13 \mathrm{Zr}$ and Ti-20Nb-30Zr alloys were shown to be passive in Ringer's solution and presented higher corrosion resistance than CP$\mathrm{Ti}$ [16]. The Ti-4Nb-15Zr alloy was also passive in Hank's solution and slightly less corrosion resistant than Ti-13Nb$13 \mathrm{Zr}$ [8]. The Ti-22Nb-6Zr alloy was passive in $0.9 \% \mathrm{NaCl}$ solution and more corrosion resistant than Ti-22Nb [22].

It is common that the passive metals undergo localized corrosion (pitting or crevice corrosion) in chloride environment, such as physiological solutions, due to the development of occluded cells. The $\mathrm{pH}$ in these occluded cells reaches acidic values which can lead to the chemical dissolution of the protective film. In applications in dental restorations, 

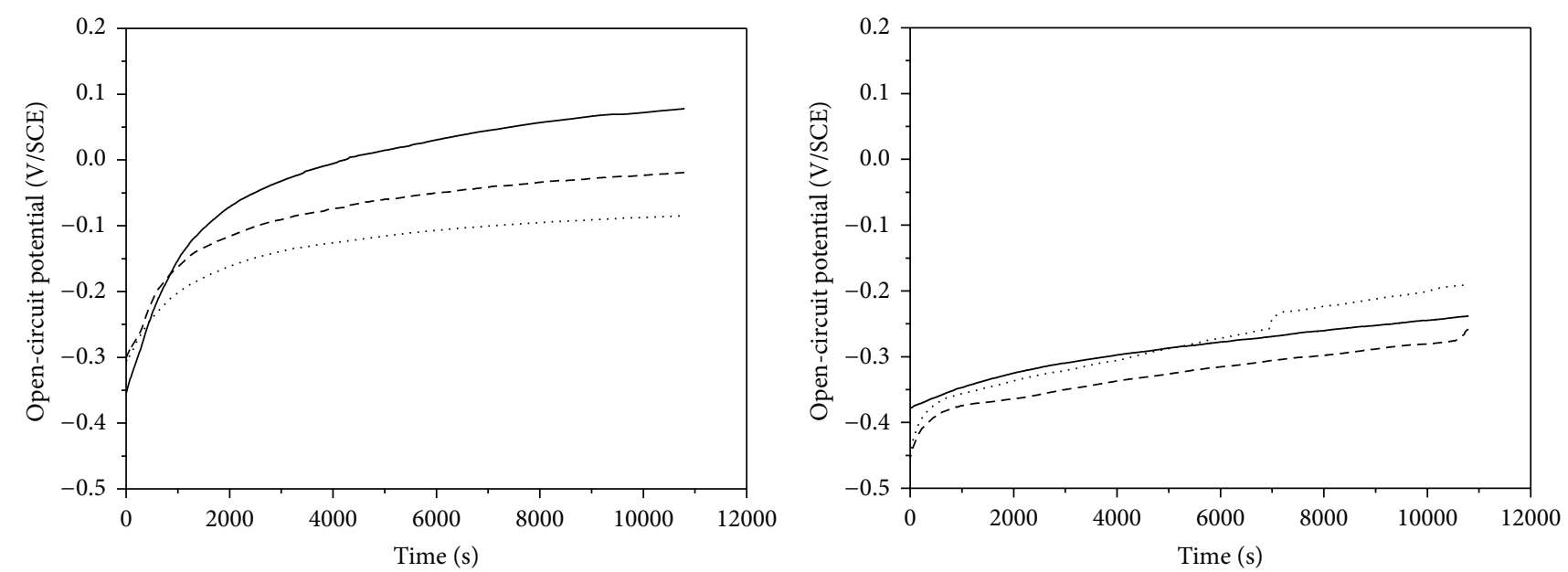

$$
\begin{aligned}
& \text { Ti, } 0 \text { ppm F } \\
& - \text { pH } 2 \\
& --- \text { pH } 5 \\
& \ldots \text {... pH } 7.5
\end{aligned}
$$

$$
\begin{aligned}
& \text { Ti-5Nb-13Zr, } 0 \text { ppm F } \\
& - \text { pH } 2 \\
& --- \text { pH } 5 \\
& \cdots \cdots \text { pH } 7.5
\end{aligned}
$$

(a)

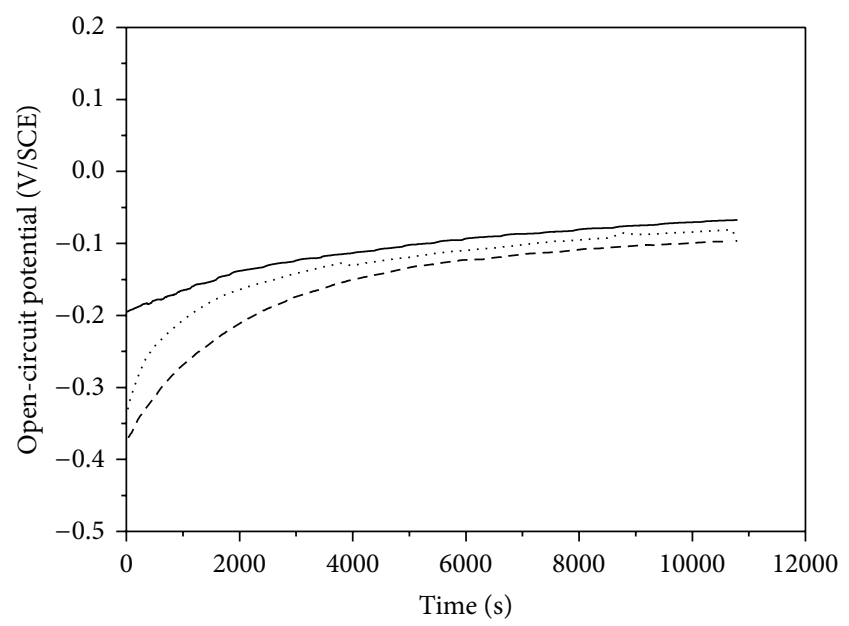

Ti-13Nb-13Zr, 0 ppm F

$$
\begin{aligned}
& \text { - } \mathrm{pH} 2 \\
& \text { - - - pH } 5 \\
& \text {..... } \mathrm{pH} 7.5
\end{aligned}
$$

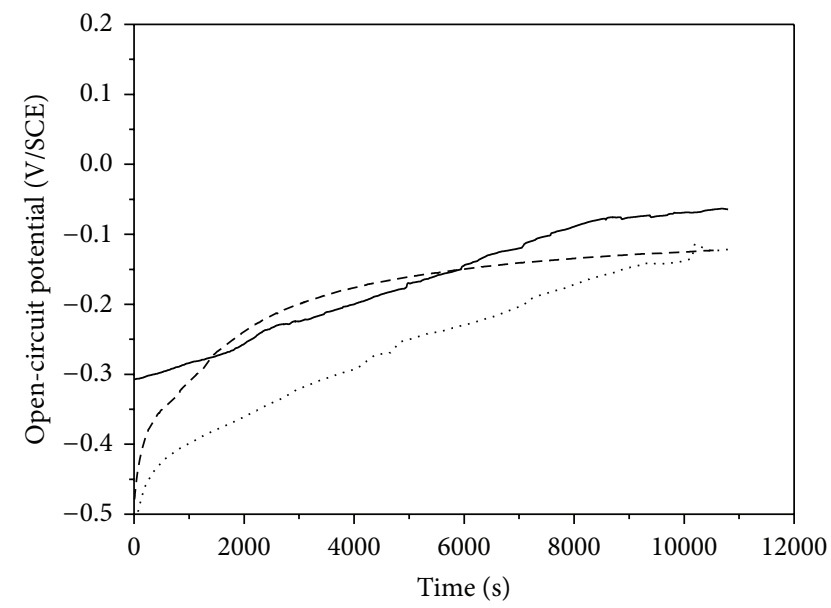

$$
\begin{aligned}
& \text { Ti-20Nb-13Zr, } 0 \text { ppm F } \\
& - \text { pH } 2 \\
& --- \text { pH } 5 \\
& \ldots \ldots \text { pH } 7.5
\end{aligned}
$$

(b)

(c)

(d)

FIGURE 1: Variation of OCP with exposure time for (a) CP-Ti, (b) Ti-5Nb-13Zr, (c) Ti-13Nb-13Zr, and (d) Ti-20Nb-13Zr in Ringer's solution of $\mathrm{pH} 2,5$, and 7.5 at $37^{\circ} \mathrm{C}$.

the implants can be also in contact with fluoride species since the fluoride-based treatments are used to prevent the dental plaque formation and the caries development. The concentration of fluorides varies from nearly $1 \mathrm{ppm}$ in drinking water, $200 \mathrm{ppm}$ in mouth rinses, and 1000-1500 ppm in toothpastes to $10000-20000 \mathrm{ppm}$ in gels, and the $\mathrm{pH}$ can range from neutral to acidic values.

The objective of this work was to study the influence of $\mathrm{pH}$ and fluoride concentration on the corrosion behavior of three Ti-xNb-13Zr alloys ( $x=5,13$, and 20) in Ringer's solution at $37^{\circ} \mathrm{C}$. The study was based on electrochemical techniques.
The results were compared with those obtained for CP-Ti under the same experimental conditions.

\section{Experimental}

The materials used in this work were as-cast grade $1 \mathrm{CP}-\mathrm{Ti}$ and the experimental Ti-5Nb-13Zr, Ti-13Nb-13Zr, and Ti-20Nb$13 \mathrm{Zr}$ alloys ( $\mathrm{wt} \%)$.

The Ti-Nb-Zr alloys were produced from commercially pure $\mathrm{Ti}, \mathrm{Zr}$, and $\mathrm{Nb}$ sheets by melting in an arc-furnace under argon atmosphere, heat-treated under vacuum at $1000^{\circ} \mathrm{C}$ for 


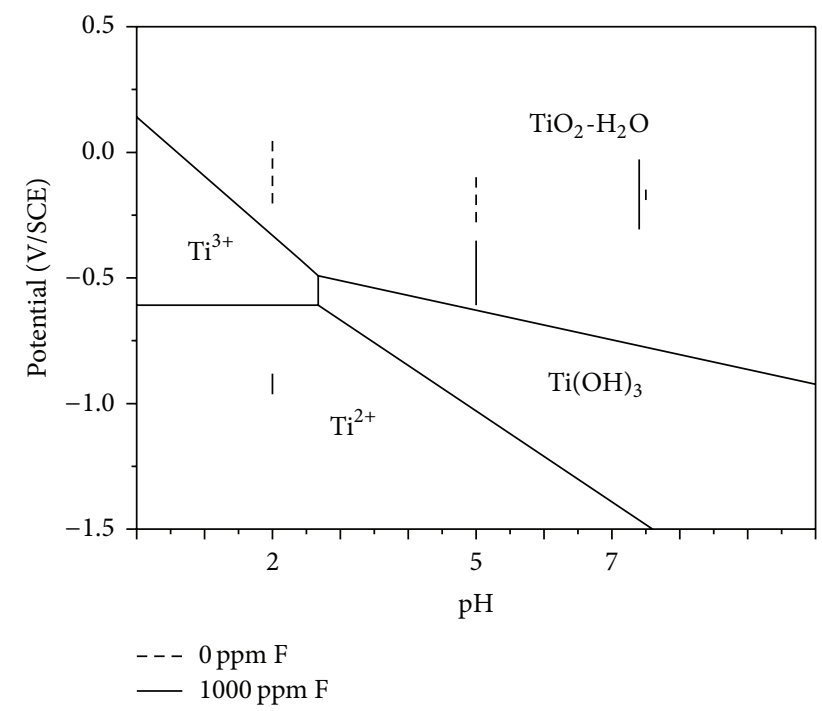

FIgURE 2: Ranges of OCP values measured after $3 \mathrm{~h}$ exposure in

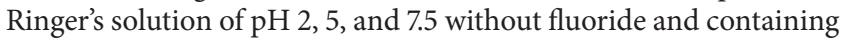
$1000 \mathrm{ppm} \mathrm{F}$ at $37^{\circ} \mathrm{C}$.

$1 \mathrm{~h}$, water-quenched, cold-swaged (around $90 \%$ reduction in area), and afterwards heat-treated at $900^{\circ} \mathrm{C}$ (temperature above the $\beta$ transus temperature) for $30 \mathrm{~min}$ under vacuum and again water-quenched. The microstructures of all materials have been presented elsewhere [16]. Ti had a characteristic as-cast microstructure, with nonhomogeneous size distribution of $\alpha$ phase grains and the Ti-Nb-Zr alloys showed a typical martensitic microstructure constituted of $\alpha^{\prime}$ hexagonal martensite. The $\alpha^{\prime \prime}$ orthorhombic martensite is also present in $\mathrm{Ti}-20 \mathrm{Nb}-13 \mathrm{Zr}$ alloy.

Cylindrical test specimens $(8 \mathrm{~mm}$ diameter and $15 \mathrm{~mm}$ length) were machined from the four materials and mounted in polytetrafluoroethylene (PTFE) holders. The cross section of the electrodes $\left(0.5 \mathrm{~cm}^{2}\right.$ area) was mechanically ground with emery paper up to 600 grit, rinsed with distilled water, and dried with acetone.

The solution was Ringer's solution [23] with the following composition: $8.6 \mathrm{~g} \mathrm{NaCl}+0.3 \mathrm{~g} \mathrm{KCl}+0.33 \mathrm{~g} \mathrm{CaCl}_{2}-2 \mathrm{H}_{2} \mathrm{O}$ in $1000 \mathrm{~mL}$ deionized water. The natural $\mathrm{pH}$ of Ringer's solution was 7.5. The solution was naturally aerated and the experiments were conducted without stirring. The temperature was maintained at $37^{\circ} \mathrm{C}$ using a thermostatic bath. The counter electrode was a square-shaped platinum sheet of $18 \mathrm{~cm}^{2}$ area. All potentials were referred to the saturated calomel electrode (SCE) potential $(=+0.242 \mathrm{~V} / \mathrm{SHE}-$ standard hydrogen electrode). The fluoride species were added to Ringer's solution using NaF P.A. salt. The pH was adjusted to 2 and 5 using dilute $\mathrm{HCl}$ solution.

Open-circuit potential (OCP), electrochemical impedance spectroscopy (EIS), and potentiodynamic polarization measurements were performed using the Electrochemical Interface SOLARTRON model 1287A and the Frequency Response Analyzer SOLARTRON model 1260 A, controlled by the Ecorr/Zplot SOLARTRON model 125587S software. Prior to polarization experiments, the working electrodes were immersed in Ringer's solution for $3 \mathrm{~h}$, taking
TABLE 1: OCP values (in V/SCE) measured after $3 \mathrm{~h}$ exposure in Ringer's solution of $\mathrm{pH} \mathrm{2,5}$, and 7.5 at $37^{\circ} \mathrm{C}$.

\begin{tabular}{lcccc}
\hline & CP-Ti & Ti-5Nb-13Zr & Ti-13Nb-13Zr & Ti-20Nb-13Zr \\
\hline pH 2 & 0.078 & -0.238 & -0.067 & -0.064 \\
pH 5 & -0.019 & -0.257 & -0.096 & -0.121 \\
pH 7.5 & -0.085 & -0.190 & -0.080 & -0.123 \\
\hline
\end{tabular}

the moment of immersion as zero time. Then, impedance measurements at OCP were performed using a sinusoidal signal of $10 \mathrm{mV}$ amplitude and frequencies in the range of $0.1 \mathrm{~Hz}-100 \mathrm{kHz}$. Cathodic and anodic polarizations were then carried out potentiodynamically with a sweep rate of $0.16 \mathrm{mV} / \mathrm{s}$. After each run, the samples were reground with emery papers to a 600-grit finish in order to remove any product formed on the metal surface which could affect the following tests, rinsed with distilled water, dried, and transferred quickly in the solution.

\section{Results and Discussion}

3.1. Corrosion Behavior in Ringer's Solution without Fluorides. Figure 1 shows the variation of OCP for CP-Ti, Ti-5Nb13Zr, Ti-13Nb-13Zr, and Ti-20Nb-13Zr in Ringer's solution

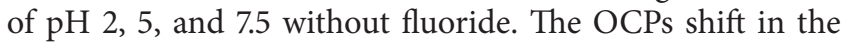
noble direction, which indicates the formation and growth of passive films on all materials. This is a general trend for Ti and Ti alloys in physiological solutions [4-10, 12-16].

The values of OCP measured after $3 \mathrm{~h}$ exposure are reported in Table 1 . As expected, all these values are found in the stability region of $\mathrm{TiO}_{2}$ of the $\mathrm{Ti}-\mathrm{H}_{2} \mathrm{O}$ Pourbaix diagram [24] (Figure 2). Nevertheless, the Ti-5Nb-13Zr alloy is the less noble material, whereas $\mathrm{CP}-\mathrm{Ti}$ is the nobler one (Table 1). It is not possible to compare the OCPs measured in this work with published data because the OCP values are highly dependent on the surface finish and heat treatments. For example, values ranging from $-0.513 \mathrm{~V}$ to $-0.064 \mathrm{~V} / \mathrm{SCE}$ were reported for Ti13Nb-13Zr alloy in Ringer's solution [10].

Figure 3 presents the polarization curves of $\mathrm{CP}-\mathrm{Ti}$, Ti$5 \mathrm{Nb}-13 \mathrm{Zr}$, Ti-13Nb-13Zr, and Ti-20Nb-13Zr in Ringer's solu-

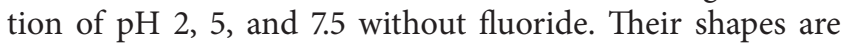
similar which shows that the anodic and cathodic reactions occurring on all materials are the same. As no active-passive transition is observed, it is confirmed that all materials are spontaneously passive in Ringer's solutions of $\mathrm{pH}$ ranging from 2 to 7.5. All materials remain passive at least up to $2.0 \mathrm{~V} / \mathrm{SCE}$. In some cases, an anodic peak is observed at nearly $1.7 \mathrm{~V} / \mathrm{SCE}$ and has been attributed to some phase change in the passivating oxide film [4].

The corrosion current densities determined by Tafel extrapolation method and the passive current densities measured at $1.0 \mathrm{~V} / \mathrm{SCE}$ in the passive region are reported in Figures 4(a) and 4(b), respectively. All the corrosion current densities are in the order of $10^{-7} \mathrm{~A} \mathrm{~cm}^{-2}$, which depicts the high corrosion resistance of all materials in Ringer's solutions of $\mathrm{pH}$ ranging from 2 to 7.5. The low values of the passive current densities (order of $10^{-6} \mathrm{~A} \mathrm{~cm}^{-2}$ ) indicate the high 

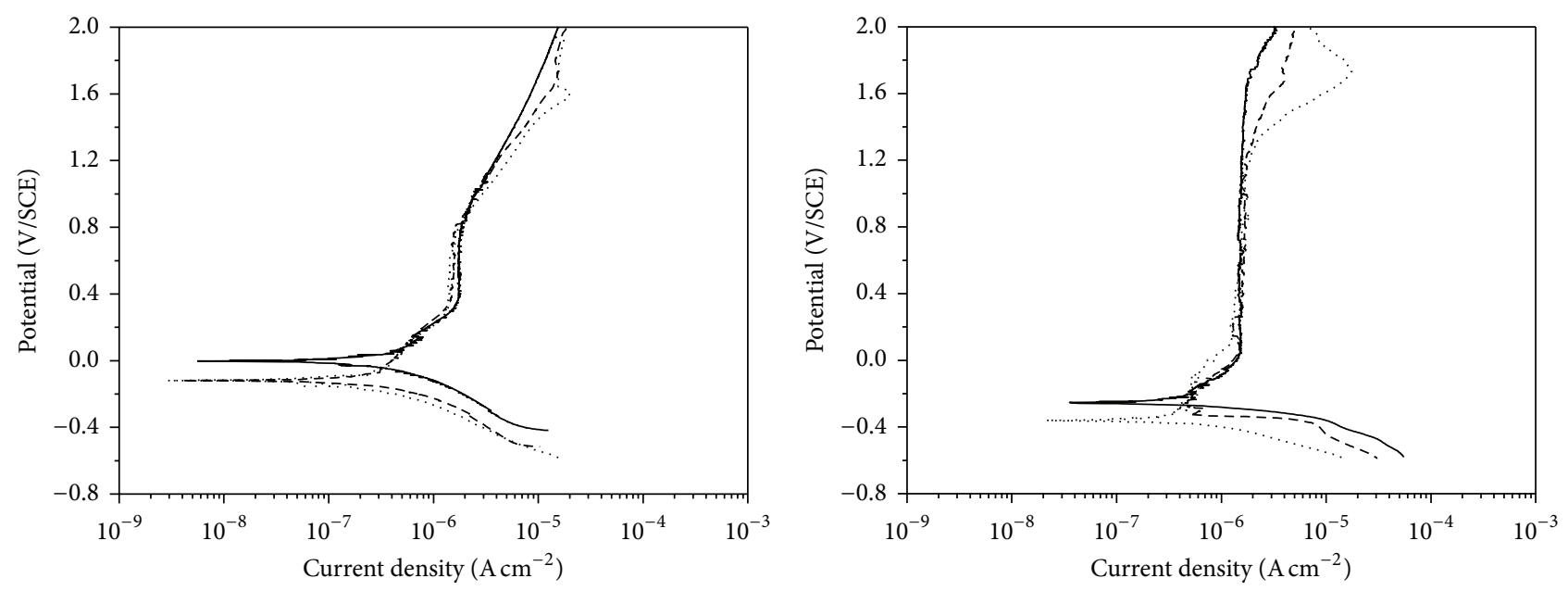

Ti, 0 ppm F

- $\mathrm{pH} 2$

- - - pH 5

…. $\mathrm{pH} 7.5$

Ti-5Nb-13Zr, 0 ppm F

$-\mathrm{pH} 2$

--- $\mathrm{pH} 5$

..... pH 7.5

(a)

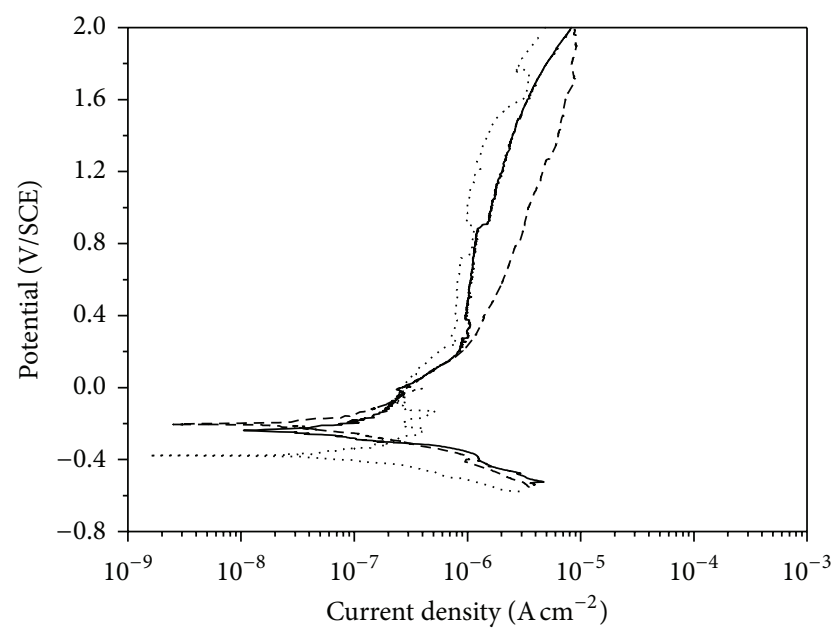

Ti-13Nb-13Zr, 0 ppm F

$-\mathrm{pH} 2$

- - - pH 5

…. $\mathrm{pH} 7.5$

(b)

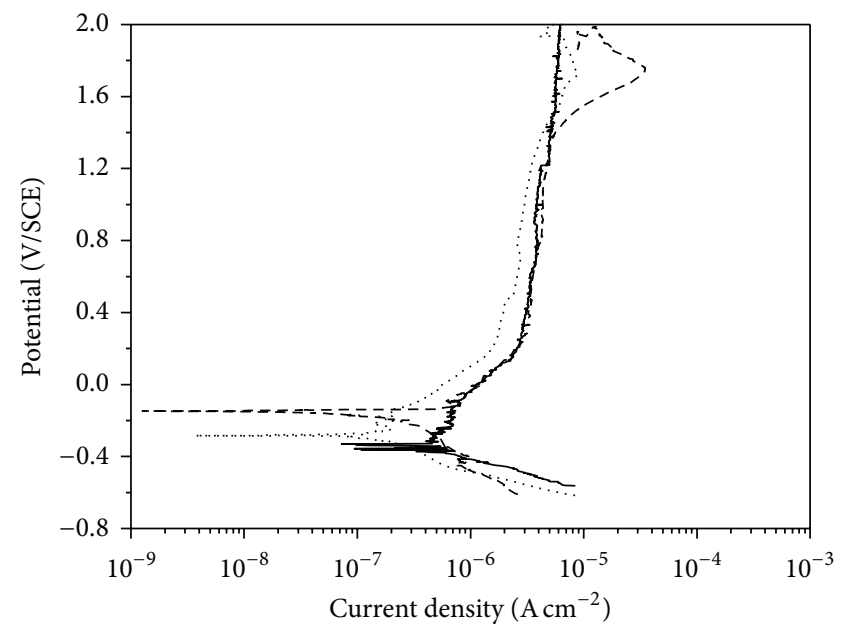

Ti-20Nb-13Zr, 0 ppm F

$-\mathrm{pH} 2$

- - - pH 5

..... $\mathrm{pH} 7.5$

(c)

(d)

Figure 3: Polarization curves of (a) CP-Ti, (b) Ti-5Nb-13Zr, (c) Ti-13Nb-13Zr, and (d) Ti-20Nb-13Zr in Ringer's solution of pH 2, 5, and 7.5 at $37^{\circ} \mathrm{C}$.

stability of the passivating films. Comparable values were obtained for CP-Ti and Ti-13Nb-13Zr alloy in Hank's solution $[14,25]$. The Ti-13Nb-13Zr alloy is a little more corrosion resistant than the $\mathrm{Ti}-5 \mathrm{Nb}-13 \mathrm{Zr}$, and $\mathrm{Ti}-20 \mathrm{Nb}-13 \mathrm{Zr}$ alloys in Ringer's solution without fluorides (Figure 4(a)), which can be related to the lower $\mathrm{Nb}$ content of $\alpha^{\prime}$ phase in $\mathrm{Ti}-5 \mathrm{Nb}-13 \mathrm{Zr}$ and the two phases $\alpha^{\prime}+\alpha^{\prime \prime}$ microstructure in Ti-20Nb-13Zr [16].

3.2. Corrosion Behavior in Ringer's Solution Containing Fluorides. Figure 5 shows the variation of OCP for CP-Ti, Ti-5Nb-13Zr, Ti-13Nb-13Zr, and Ti-20Nb-13Zr in Ringer's solution of $\mathrm{pH} 2,5$, and 7.5 containing 1000 ppm fluorides. For $\mathrm{pH} 7.5$, the OCPs shift in the noble direction, which indicates the formation and growth of passive films on all materials. The OCP values measured after $3 \mathrm{~h}$ exposure under this condition (Table 2) are found in the stability region of $\mathrm{TiO}_{2}$ of the Ti- $\mathrm{H}_{2} \mathrm{O}$ Pourbaix diagram [24] (Figure 2), which depicts a passive behavior. In Ringer's solution of $\mathrm{pH} 2$, the OCPs stabilize to very negative values (Table 2 ) that are found in the stability region of $\mathrm{Ti}$ ions of the $\mathrm{Ti}-\mathrm{H}_{2} \mathrm{O}$ Pourbaix diagram [24] (Figure 2), indicating a spontaneous active behavior. For $\mathrm{pH} 5$, although the OCP values are nearly -0.3 to $-0.2 \mathrm{~V}$ less noble than the values obtained for $\mathrm{pH} 7.5$ (Table 2), they are 


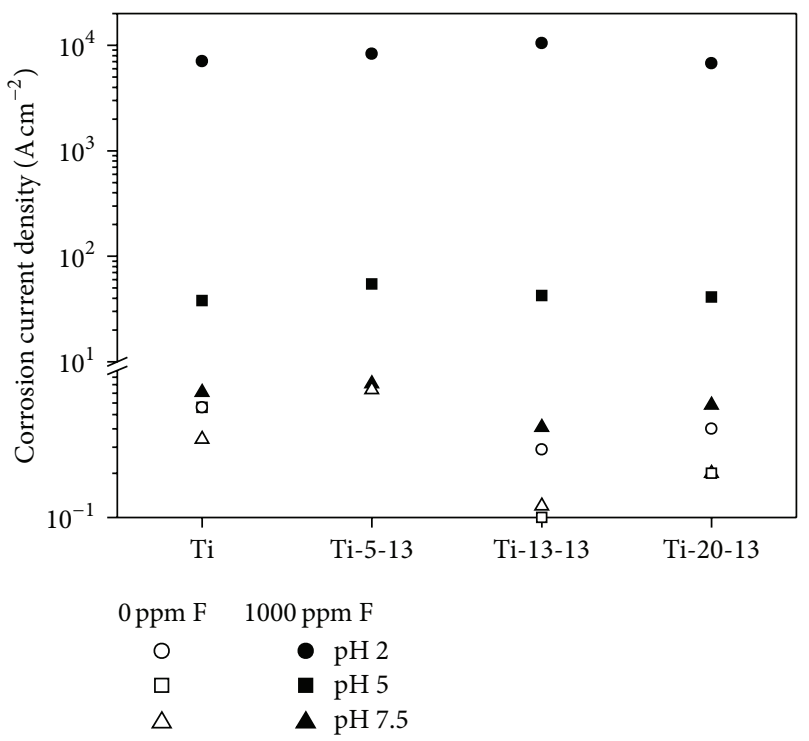

(a)

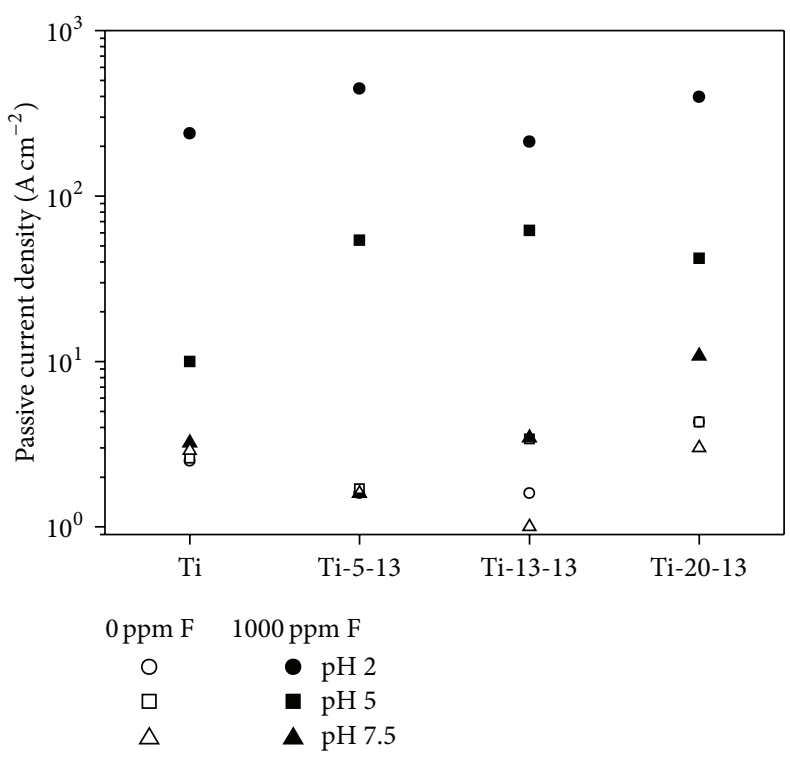

(b)

FIgURE 4: (a) Corrosion current densities and (b) passive current densities (measured at 1.0 V/SCE) of CP-Ti, Ti-5Nb-13Zr, Ti-13Nb-13Zr, and Ti-20Nb-13Zr in Ringer's solution of $\mathrm{pH} 2,5$, and 7.5 without fluoride and containing $1000 \mathrm{ppm} \mathrm{F}$ at $37^{\circ} \mathrm{C}$.

TABLE 2: OCP values (in V/SCE) measured after $3 \mathrm{~h}$ exposure in Ringer's solution of $\mathrm{pH} 2,5$, and 7.5 containing $1000 \mathrm{ppm} \mathrm{F}$ at $37^{\circ} \mathrm{C}$.

\begin{tabular}{lcccc}
\hline & CP-Ti & Ti-5Nb-13Zr & Ti-13Nb-13Zr & Ti-20Nb-13Zr \\
\hline pH 2 & -0.964 & -0.887 & -0.890 & -0.881 \\
pH 5 & -0.353 & -0.537 & -0.493 & -0.509 \\
pH 7.5 & -0.028 & -0.308 & -0.074 & -0.143 \\
\hline
\end{tabular}

TABLE 3: Calculated concentrations of $\mathrm{F}^{-}, \mathrm{HF}_{2}^{-}$, and $\mathrm{HF}$ for $\mathrm{pH} 2,5$, and 7.5 and $1000 \mathrm{ppm}$ total fluoride concentration.

\begin{tabular}{lccc}
\hline & pH 2 & pH 5 & pH 7.5 \\
\hline$\left[\mathrm{F}^{-}\right] / \mathrm{ppm}$ & 104 & 973 & 988 \\
{$\left[\mathrm{HF}_{2}^{-}\right] / \mathrm{ppm}$} & 86 & 8 & 0 \\
{$[\mathrm{HF}] / \mathrm{ppm}$} & 841 & 8 & 0 \\
\hline
\end{tabular}

also found in the stability region of $\mathrm{TiO}_{2}$ (Figure 2), showing the passive behavior of all the materials.

Nakagawa et al. [26] show from OCP measurements of Ti-6Al-4V alloy in artificial saliva that there is a welldefined correlation between $\mathrm{pH}$ and fluoride concentration that determines the spontaneous (active or passive) behavior of the alloy. The combination of low $\mathrm{pH}$ and fluoride presence has been shown to enhance passive film dissolution on CP-Ti, Ti-6Al-4V, and Ti-Ta alloys [26-28].

The anodic polarization curves of CP-Ti, Ti-5Nb-13Zr, Ti$13 \mathrm{Nb}-13 \mathrm{Zr}$, and Ti-20Nb-13Zr in Ringer's solution of $\mathrm{pH} 5$ and 7.5 containing $1000 \mathrm{ppm}$ fluorides are characteristic of passive materials (Figure 6). Nevertheless, the anodic current densities measured for $\mathrm{pH} 5$ present higher values, which is indicative of a lower stability of the passive films. In Ringer's solution of $\mathrm{pH} 2$, the anodic polarization curves present an activepassive transition, which corroborates the spontaneous active behavior of all materials at OCP under this condition. Similar results were obtained for $\mathrm{Ti}$, Ti-6Al-4V, and Ti-23Ta alloys in artificial saliva containing $1000 \mathrm{ppm}$ fluorides [28].

The corrosion current densities and the passive current densities measured at 1.0 V/SCE determined in Ringer's solution of $\mathrm{pH} 7.5$ are close to the values obtained in solutions without fluorides (Figure 4). This indicates that, in neutral solution, the presence of fluoride has little effect on the corrosion resistance and the stability of the passive films.

On the contrary, the corrosion current densities and the passive current densities increased nearly 1-2 and 2-3 orders of magnitude in Ringer's solutions of $\mathrm{pH} 5$ and $\mathrm{pH}$ 2 , respectively, when compared to the values measured for pH 7.5 (Figure 4). Thus, in solutions containing fluorides, the corrosion resistance and the stability of the passive films decrease with decreasing $\mathrm{pH}$. The same trend is observed for all materials.

When in the passive state (in Ringer's solution of $\mathrm{pH} 5$ and 7.5 containing $1000 \mathrm{ppm}$ fluorides), the Ti- $13 \mathrm{Nb}-13 \mathrm{Zr}$ alloy is also a little more corrosion resistant than the Ti-5Nb-13Zr and Ti-20Nb-13Zr alloys (Figure 4(a)).

The higher corrosiveness of low $\mathrm{pH}$ aqueous solution containing fluorides has been attributed to the presence of $\mathrm{HF}_{2}{ }^{-}$ or HF species [29]. The concentrations of $\mathrm{F}^{-}, \mathrm{HF}_{2}{ }^{-}$and $\mathrm{HF}$ are dependent on $\mathrm{pH}$ and total fluoride concentration and can be calculated from the equilibria constants and mass conservation equation [30]. Table 3 reports the calculated concentrations of $\mathrm{F}^{-}, \mathrm{HF}_{2}{ }^{-}$, and $\mathrm{HF}$ for $\mathrm{pH} 2,5$, and 7.5 and $1000 \mathrm{ppm}$ 

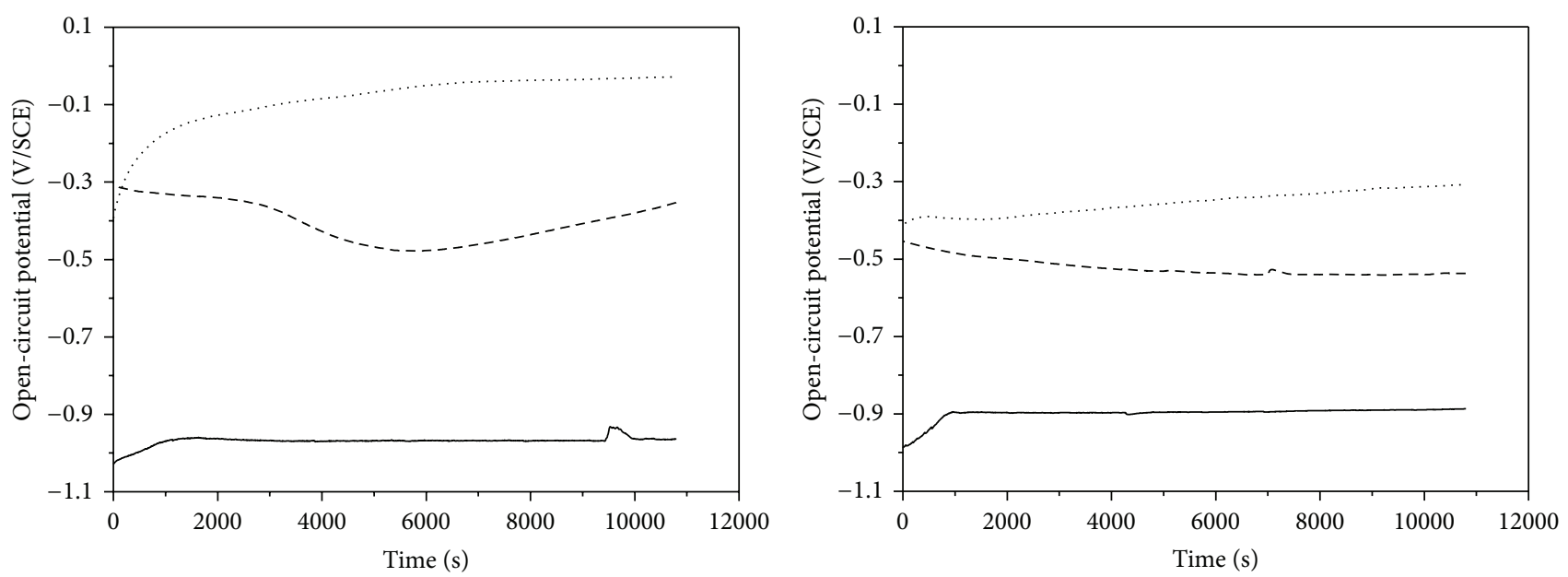

Ti, 1000 ppm F

$-\mathrm{pH} 2$

--- $\mathrm{pH} 5$

…. $\mathrm{pH} 7.5$

Ti-5Nb-13Zr, 1000 ppm F

$-\mathrm{pH} 2$

$---\mathrm{pH} 5$

…. $\mathrm{pH} 7.5$

(a)

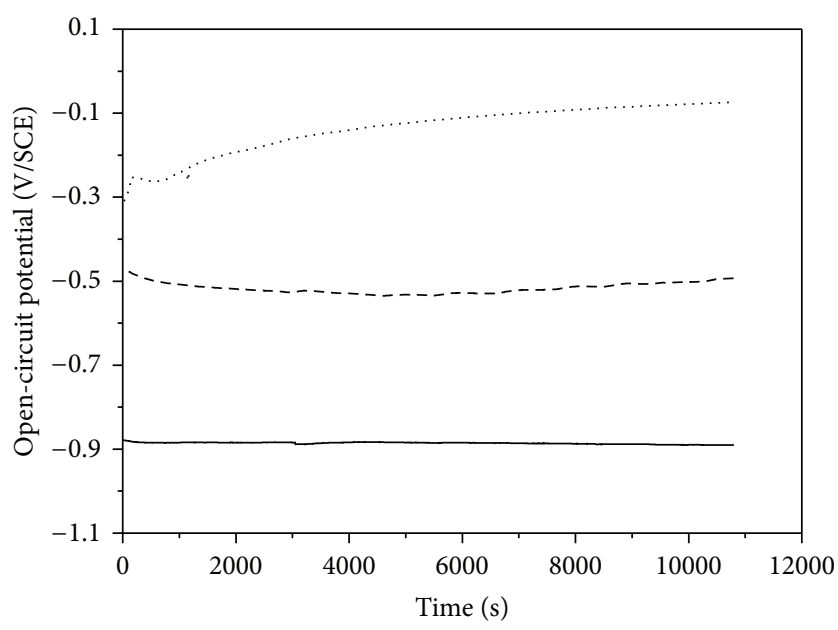

Ti-13Nb-13Zr, 1000 ppm F

- $\mathrm{pH} 2$

- - - pH 5

…. $\mathrm{pH} 7.5$

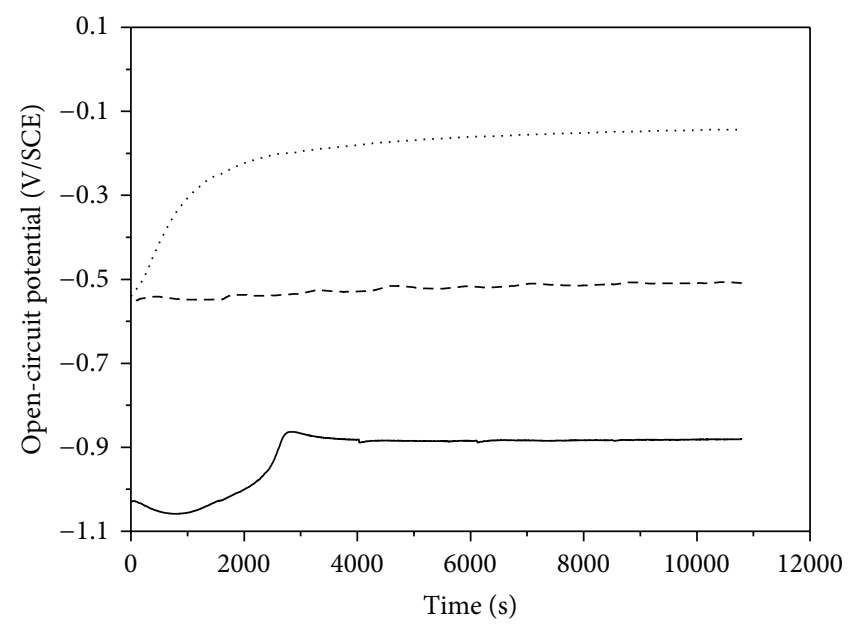

Ti-20Nb-13Zr, 1000 ppm F

$-\mathrm{pH} 2$

- - - pH 5

…. $\mathrm{pH} 7.5$

(c)

(d)

FIgure 5: Variation of OCP with exposure time for (a) CP-Ti, (b) Ti-5Nb-13Zr, (c) Ti-13Nb-13Zr, and (d) Ti-20Nb-13Zr in Ringer's solution of $\mathrm{pH} 2,5$, and 7.5 containing $1000 \mathrm{ppm} \mathrm{F}$ at $37^{\circ} \mathrm{C}$.

total fluoride concentration. It is clear that the active behavior of the materials in Ringer's solution of $\mathrm{pH} 2$ containing $1000 \mathrm{ppm} \mathrm{F}$ is related to the high concentration of $\mathrm{HF}$.

3.3. EIS Results. The Bode diagrams obtained at OCP in Ringer's solution of $\mathrm{pH} \mathrm{2,5}$, and 7.5 without fluorides and of $\mathrm{pH} 7.5$ containing $1000 \mathrm{ppm}$ fluorides present a linear relation (slope close to -1 ) between log |Impedance| and log (Frequency) and a phase angle near $-90^{\circ}$ from the low to intermediate frequencies (Figures 7 and 8). For CP-Ti, this is limited to a narrower frequency range, which is indicative of a lower stability of the oxide film formed on CP-Ti (Figures 7(a) and $8(a))$. All these results depict a predominantly capacitive behavior of the metal/solution interface, characteristic of passive materials. In Ringer's solution of $\mathrm{pH} 5$ containing fluorides, although the four materials are passive, the oxide layers are less capacitive, which can be related to their lower stability. Bode diagrams of the same shape and impedance values of the same order of magnitude were obtained for many other Ti alloys in physiological solutions [11, 31, 32].

Very low impedance values were measured in Ringer's solution of pH 2 containing 1000 ppm fluorides, which confirms the active state of all materials under these conditions. Impedance values of few tens of $\Omega \mathrm{cm}^{2}$ were also measured for 

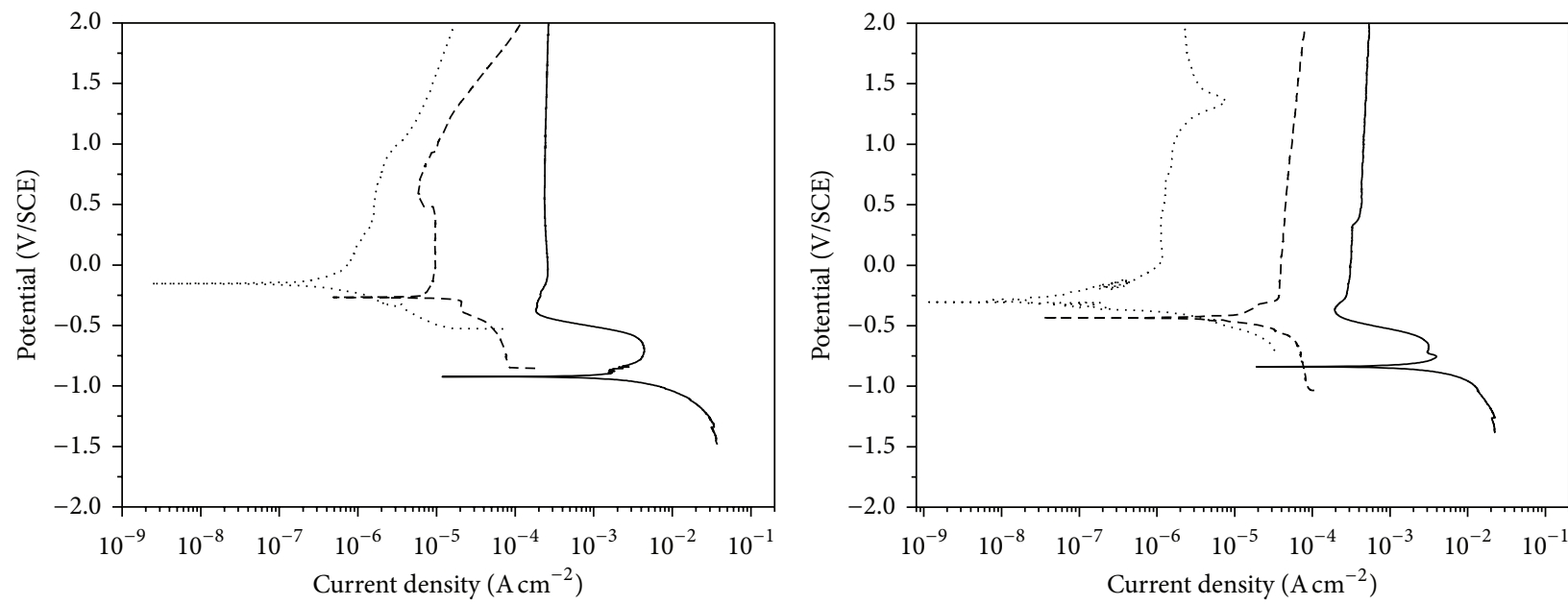

Ti, $1000 \mathrm{ppm} \mathrm{F}$

$-\mathrm{pH} 2$

- - - pH 5

…. $\mathrm{pH} 7.5$

Ti-5Nb-13Zr, 1000 ppm F

$-\mathrm{pH} 2$

-- $\mathrm{pH} 5$

…. $\mathrm{pH} 7.5$

(a)

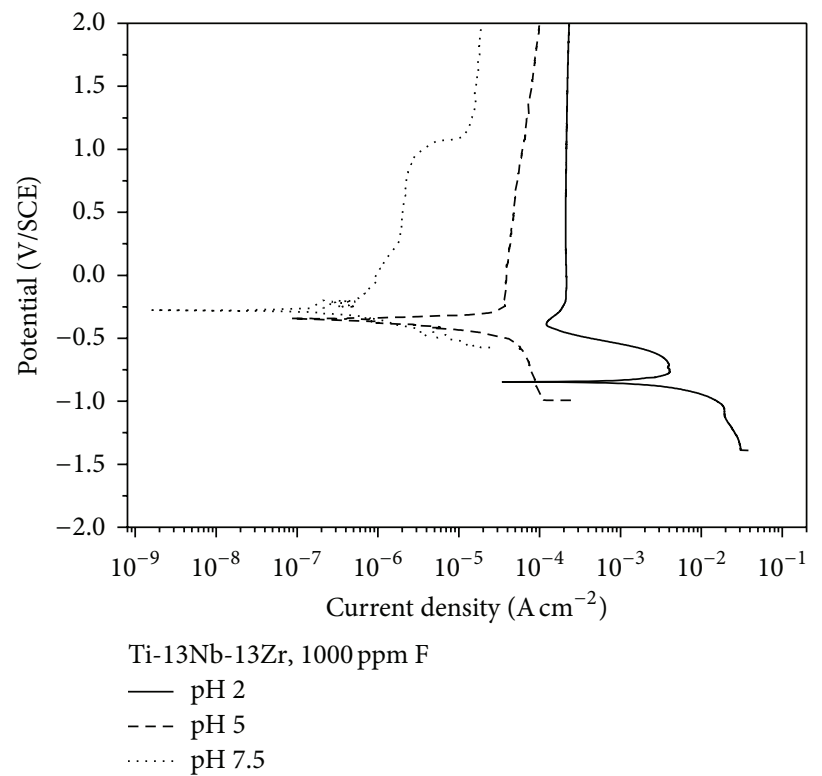

(c)

(d)

Figure 6: Polarization curves of (a) CP-Ti, (b) Ti-5Nb-13Zr, (c) Ti-13Nb-13Zr, and (d) Ti-20Nb-13Zr in Ringer's solution of pH 2, 5, and 7.5 containing $1000 \mathrm{ppm} \mathrm{F}$ at $37^{\circ} \mathrm{C}$.

TABLE 4: Impedance modulus (in $\left.\Omega \mathrm{cm}^{2}\right)$ at low frequency $(=0.1 \mathrm{~Hz})$ in Ringer's solution of $\mathrm{pH} 2,5$, and 7.5 without fluorides and containing $1000 \mathrm{ppm} \mathrm{F}$ at $37^{\circ} \mathrm{C}$.

\begin{tabular}{|c|c|c|c|c|}
\hline & CP-Ti & Ti-5Nb-13Zr & Ti-13Nb-13Zr & Ti-20Nb-13Zr \\
\hline \multicolumn{5}{|l|}{0 ppm F } \\
\hline $\mathrm{pH} 2$ & 21227 & 33371 & 76491 & 40350 \\
\hline pH 5 & 30543 & 52854 & 110420 & 57979 \\
\hline $\mathrm{pH} 7.5$ & 33725 & 69234 & 110647 & 62797 \\
\hline \multicolumn{5}{|c|}{$1000 \mathrm{ppm} \mathrm{F}$} \\
\hline pH 2 & 18 & 15 & 14 & 12 \\
\hline pH 5 & 7010 & 2054 & 2525 & 1926 \\
\hline pH 7.5 & 24495 & 53785 & 64752 & 45122 \\
\hline
\end{tabular}




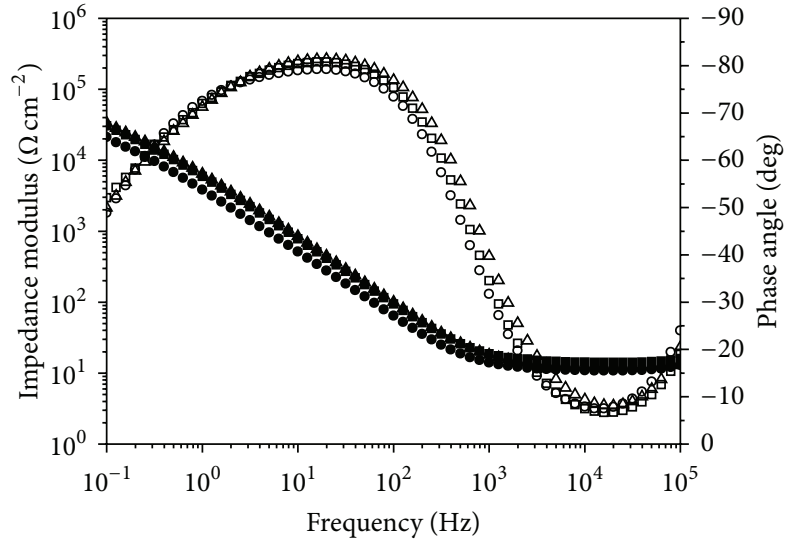

Ti, 0 ppm F

- $\circ \mathrm{pH} 2$

- $\mathrm{pH} 5$

$\Delta \Delta \mathrm{pH} 7.5$

(a)

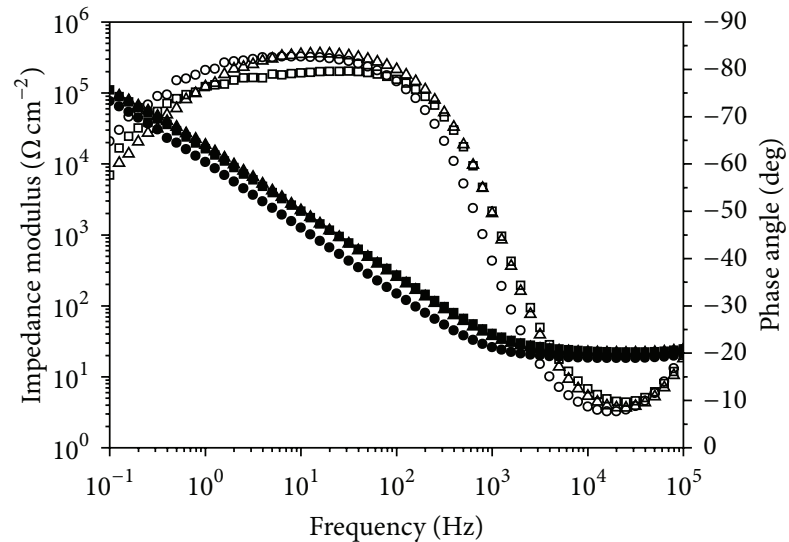

Ti-13Nb-13Zr, 0 ppm F

- $\circ \mathrm{pH} 2$

- $\square \mathrm{pH} 5$

$\Delta \Delta \mathrm{pH} 7.5$

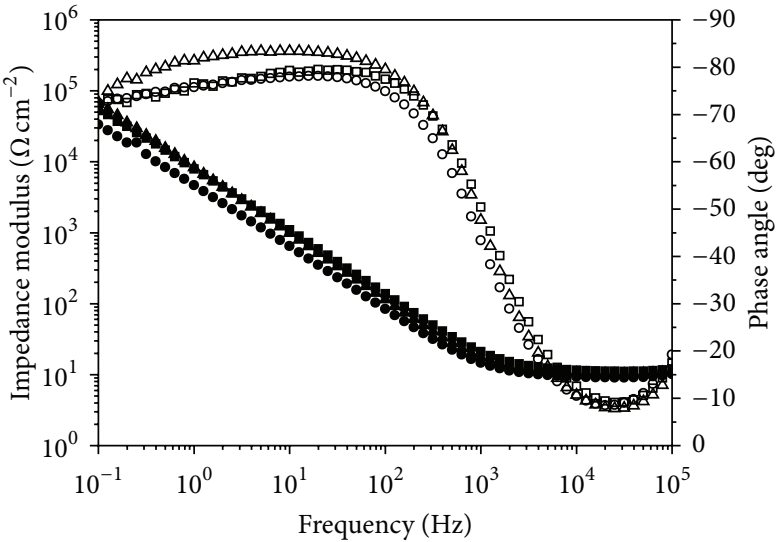

Ti-5Nb-13Zr, 0 ppm F

- $\circ \mathrm{pH} 2$

- $\square \mathrm{pH} 5$

- $\Delta \mathrm{pH} 7.5$

(b)

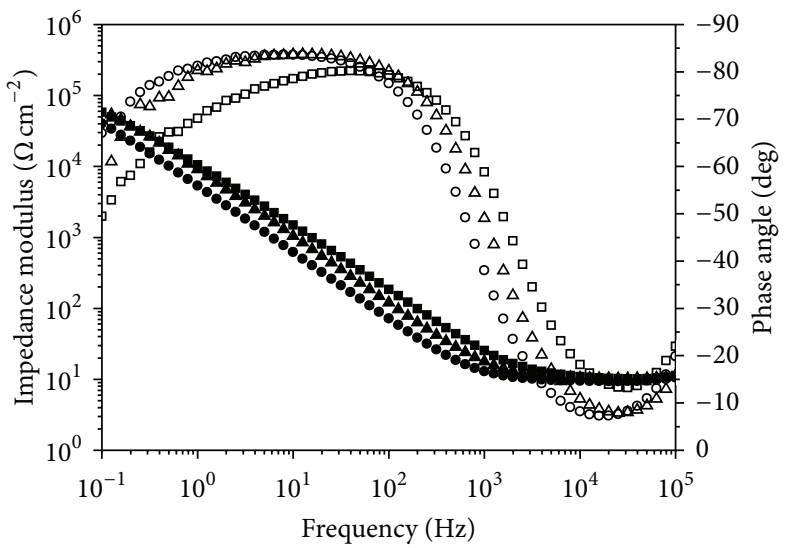

Ti-20Nb-13Zr, 0 ppm F

- $\circ \mathrm{pH} 2$

- $\mathrm{pH} 5$

$\Delta \mathrm{pH} 7.5$

(c)

(d)

Figure 7: Bode diagrams of (a) CP-Ti, (b) Ti-5Nb-13Zr, (c) Ti-13Nb-13Zr, and (d) Ti-20Nb-13Zr obtained at OCP in Ringer's solution of pH 2,5 , and 7.5 at $37^{\circ} \mathrm{C}$.

Ti-23Ta alloy in artificial saliva of $\mathrm{pH} 2$ containing $1000 \mathrm{ppm}$ fluorides [33] and for $\mathrm{Ti}$ and $\mathrm{Ti}-6 \mathrm{Al}-4 \mathrm{~V}$ alloy in artificial saliva of $\mathrm{pH} 3$ containing $0.01 \mathrm{M} \mathrm{NaF}$ [34].

For comparison, the corrosion resistance of the materials can be estimated by the values of impedance modulus at low frequencies (Table 4). The impedance results confirm that the Ti-13Nb-13Zr alloy is a little more corrosion resistant than the Ti-5Nb-13Zr and Ti-20Nb-13Zr alloys. In most conditions, the $\mathrm{Ti}-\mathrm{Nb}-\mathrm{Zr}$ alloys presented higher corrosion resistance than CP-Ti.

\section{Conclusions}

The corrosion behaviour of CP-Ti, Ti-5Nb-13Zr, Ti-13Nb$13 \mathrm{Zr}$, and Ti-20Nb-13Zr alloys was investigated in Ringer's solution of $\mathrm{pH} 2,5$, and 7.5 without fluorides and containing $1000 \mathrm{ppm} \mathrm{F}$ at $37^{\circ} \mathrm{C}$. The results showed the following.

(i) All materials present a passive behavior in Ringer's solution without fluorides independently on the $\mathrm{pH}$ values.

(ii) All materials present a passive behavior in Ringer's solution of $\mathrm{pH} 5$ and 7.5 containing fluorides.

(iii) All materials present an active behavior in Ringer's solution of $\mathrm{pH} 2$ containing $1000 \mathrm{ppm}$ fluorides, which was attributed to the presence of HF species.

(iv) The corrosion resistance of all materials in Ringer's solution decreases with both decrease of $\mathrm{pH}$ and addition of fluorides. 


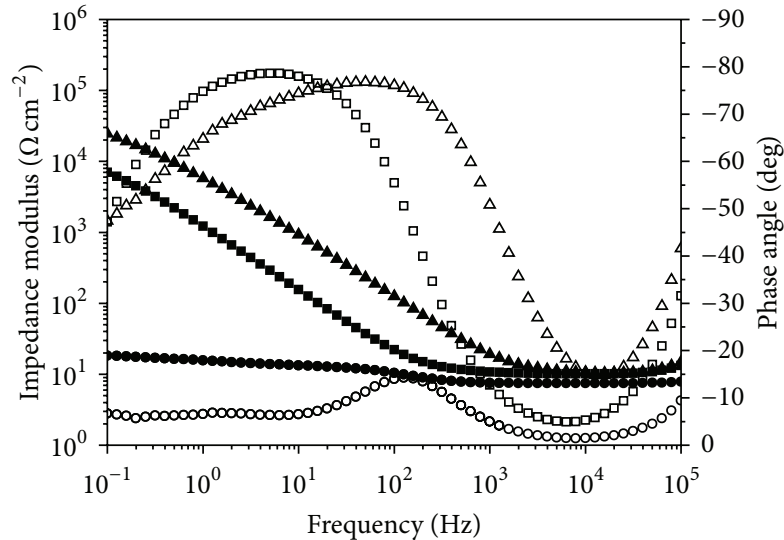

Ti, 1000 ppm F

- $\circ \mathrm{pH} 2$

- $\square \mathrm{pH} 5$

$\Delta \mathrm{pH} 7.5$

(a)

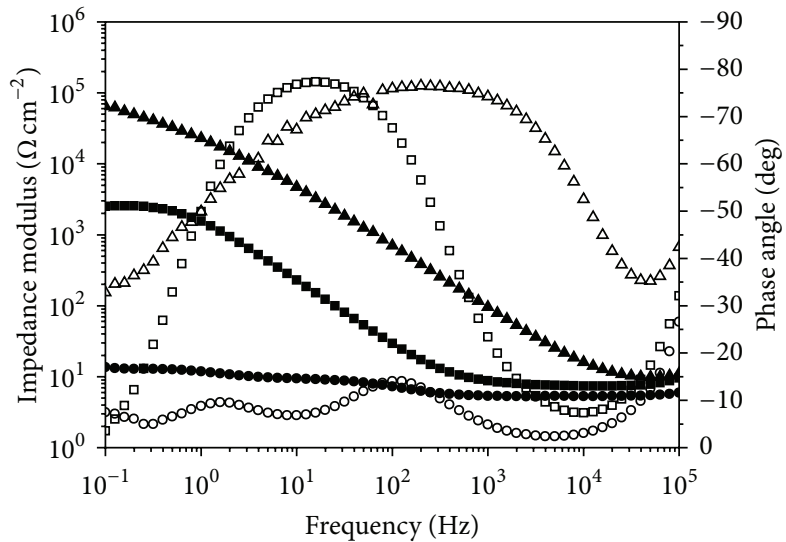

Ti-13Nb-13Zr, 1000 ppm F

- $\circ \mathrm{pH} 2$

- $\square \mathrm{pH} 5$

$\Delta \Delta \mathrm{pH} 7.5$

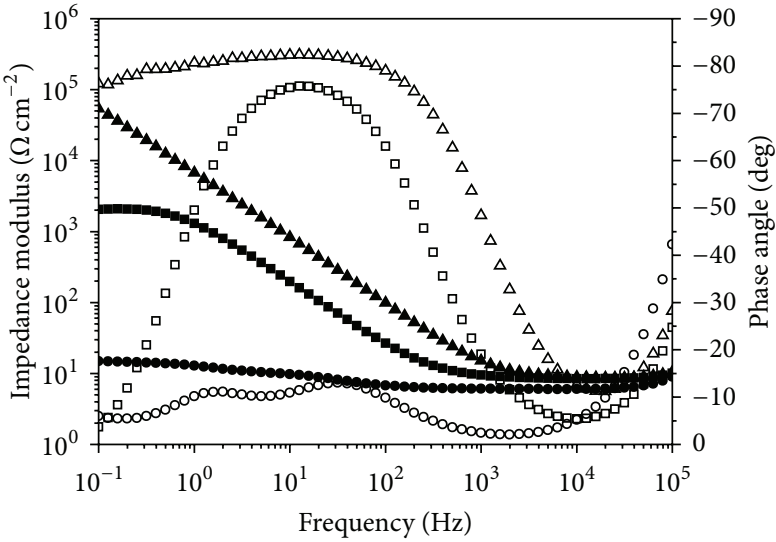

Ti-5Nb-13Zr, 1000 ppm F

- $\circ \mathrm{pH} 2$

- $\square \mathrm{pH} 5$

$\Delta \quad \Delta \mathrm{pH} 7.5$

(b)

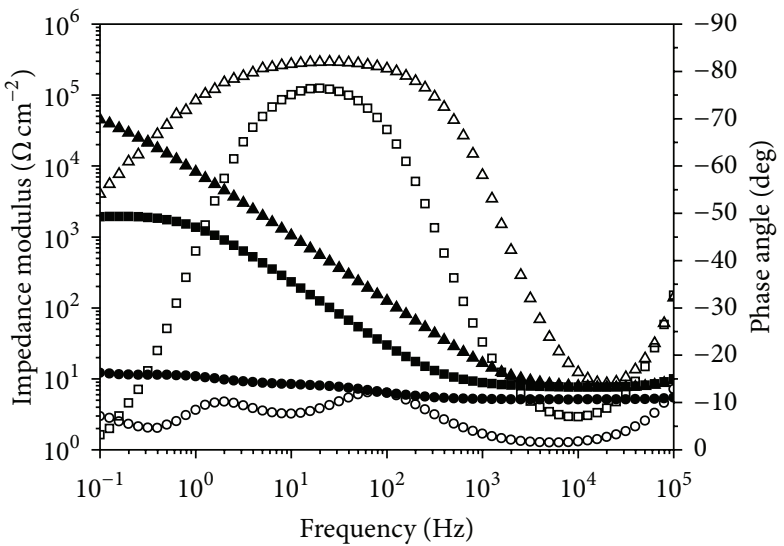

Ti-20Nb-13Zr, 1000 ppm F

- $\circ \mathrm{pH} 2$

- $\square \mathrm{pH} 5$

$\Delta \Delta \mathrm{pH} 7.5$

(c)

(d)

Figure 8: Bode diagrams of (a) CP-Ti, (b) Ti-5Nb-13Zr, (c) Ti-13Nb-13Zr, and (d) Ti-20Nb-13Zr obtained at OCP in Ringer's solution of pH 2,5 , and 7.5 containing $1000 \mathrm{ppm} \mathrm{F}$ at $37^{\circ} \mathrm{C}$.

(v) Ti-13Nb-13Zr alloy is a little more corrosion resistant than the Ti-5Nb-13Zr and Ti-20Nb-13Zr alloys and, in most conditions, the Ti-Nb-Zr alloys present higher corrosion resistance than CP-Ti.

\section{Acknowledgment}

The authors acknowledge Dr. Sandra G. Schneider (EELUSP-Brazil) for supplying the Ti-Nb-Zr alloys.

\section{References}

[1] F. H. Jones, "Teeth and bones: applications of surface science to dental materials and related biomaterials," Surface Science Reports, vol. 42, no. 3-5, pp. 75-205, 2001.
[2] J. Black, H. Sherk, J. Bonini, W. R. Rostoker, and J. O. Galante, "Metallosis associated with a stable titanium-alloy femoral component in total hip replacement. A case report," Journal of Bone and Joint Surgery A, vol. 72, no. 1, pp. 126-130, 1990.

[3] H. C. Amstutz, P. Campbell, N. Kossovsky, and I. C. Clarke, "Mechanism and clinical significance of wear debris-induced osteolysis," Clinical Orthopaedics and Related Research, no. 276, pp. 7-17, 1991.

[4] S. Y. Yu and J. R. Scully, "Corrosion and passivity of Ti-13\% $\mathrm{Nb}-13 \% \mathrm{Zr}$ in comparison to other biomedical implant alloys," Corrosion, vol. 53, no. 12, pp. 965-976, 1997.

[5] M. A. Khan, R. L. Williams, and D. F. Williams, "In-vitro corrosion and wear of titanium alloys in the biological environment," Biomaterials, vol. 17, no. 22, pp. 2117-2126, 1996.

[6] M. A. Khan, R. L. Williams, and D. F. Williams, "Conjoint corrosion and wear in titanium alloys," Biomaterials, vol. 20, no. 8, pp. 765-772, 1999. 
[7] M. A. Khan, R. L. Williams, and D. F. Williams, "The corrosion behaviour of Ti-6Al-4V, Ti-6Al-7Nb and Ti-13Nb-13Zr in protein solutions," Biomaterials, vol. 20, no. 7, pp. 631-637, 1999.

[8] M. F. López, A. Gutiérrez, and J. A. Jiménez, "In vitro corrosion behaviour of titanium alloys without vanadium," Electrochimica Acta, vol. 47, no. 9, pp. 1359-1364, 2002.

[9] Z. Cai, T. Shafer, I. Watanabe, M. E. Nunn, and T. Okabe, "Electrochemical characterization of cast titanium alloys," Biomaterials, vol. 24, no. 2, pp. 213-218, 2003.

[10] M. Geetha, U. K. Mudali, A. K. Gogia, R. Asokamani, and B. Raj, "Influence of microstructure and alloying elements on corrosion behavior of Ti-13Nb-13Zr alloy," Corrosion Science, vol. 46, no. 4, pp. 877-892, 2004.

[11] A. K. Shukla and R. Balasubramaniam, "Effect of surface treatment on electrochemical behavior of $\mathrm{CP} \mathrm{Ti}$, Ti-6Al-4V and Ti-13Nb-13Zr alloys in simulated human body fluid," Corrosion Science, vol. 48, no. 7, pp. 1696-1720, 2006.

[12] N. T. C. Oliveira, E. A. Ferreira, L. T. Duarte, S. R. Biaggio, R. C. Rocha-Filho, and N. Bocchi, "Corrosion resistance of anodic oxides on the Ti-50Zr and Ti-13Nb-13Zr alloys," Electrochimica Acta, vol. 51, no. 10, pp. 2068-2075, 2006.

[13] S. L. de Assis, S. Wolynec, and I. Costa, "Corrosion characterization of titanium alloys by electrochemical techniques," Electrochimica Acta, vol. 51, no. 8-9, pp. 1815-1819, 2006.

[14] A. Choubey, B. Basu, and R. Balasubramaniam, "Electrochemical behavior of Ti-based alloys in simulated human body fluid environment," Trends in Biomaterials and Artificial Organs, vol. 18, no. 2, pp. 64-72, 2005.

[15] S. L. Assis and I. Costa, "Electrochemical evaluation of Ti-13Nb13Zr, Ti-6Al-4V and Ti-6Al-7Nb alloys for biomedical application by long-term immersion tests," Materials and Corrosion, vol. 58, no. 5, pp. 329-333, 2007.

[16] A. Robin, O. A. S. Carvalho, S. G. Schneider, and S. Schneider, "Corrosion behavior of Ti-xNb-13Zr alloys in Ringer's solution," Materials and Corrosion, vol. 59, no. 12, pp. 929-933, 2008.

[17] I. Cvijović-Alagić, Z. Cvijović, S. Mitrović, V. Panić, and M. Rakin, "Wear and corrosion behaviour of Ti-13Nb-13Zr and Ti$6 \mathrm{Al}-4 \mathrm{~V}$ alloys in simulated physiological solution," Corrosion Science, vol. 53, no. 2, pp. 796-808, 2011.

[18] K. S. Suresh, M. Geetha, C. Richard et al., "Effect of equal channel angular extrusion on wear and corrosion behavior of the orthopedic Ti-13Nb-13Zr alloy in simulated body fluid," Materials Science and Engineering C, vol. 32, no. 4, pp. 763-771, 2012.

[19] L. T. Duarte, S. R. Biaggio, R. C. Rocha-Filho, and N. Bocchi, "Surface characterization of oxides grown on the Ti-13Nb-13Zr alloy and their corrosion protection," Corrosion Science, vol. 72, pp. 35-40, 2013.

[20] J. M. C. Moreno, C. Vasilescu, S. I. Drob, E. I. Neacsu, and M. Popa, "Evaluation of the microstructural, mechanical and anti-corrosive properties of a new ternary Ti-15Zr-5Nb alloy in simulated oral environment," Materials and Corrosion, 2013.

[21] M. Geetha, A. K. Singh, A. K. Gogia, and R. Asokamani, "Effect of thermomechanical processing on evolution of various phases in Ti-Nb-Zr alloys," Journal of Alloys and Compounds, vol. 384, no. 1-2, pp. 131-144, 2004.

[22] B. L. Wang, Y. F. Zheng, and L. C. Zhao, "Electrochemical corrosion behavior of biomedical Ti-22Nb and Ti-22Nb-6Zr alloys in saline medium," Materials and Corrosion, vol. 60, no. 10, pp. 788-794, 2009.

[23] R. Baboian, Corrosion Tests and Standards: Application and Interpretation, ASTM, Philadelphia, Pa, USA, 1995.
[24] M. Pourbaix, Atlas of Electrochemical Equilibria in Aqueous Solutions, Pergamon Press, New York, NY, USA, 1966.

[25] A. Choubey, R. Balasubramaniam, and B. Basu, "Effect of replacement of $\mathrm{V}$ by $\mathrm{Nb}$ and $\mathrm{Fe}$ on the electrochemical and corrosion behavior of Ti-6Al-4V in simulated physiological environment," Journal of Alloys and Compounds, vol. 381, no. 1-2, pp. 288-294, 2004.

[26] M. Nakagawa, S. Matsuya, and K. Udoh, "Effects of fluoride and dissolved oxygen concentrations on the corrosion behavior of pure titanium and titanium alloys," Dental Materials Journal, vol. 21, no. 2, pp. 83-92, 2002.

[27] N. Schiff, B. Grosgogeat, M. Lissac, and F. Dalard, "Influence of fluoride content and $\mathrm{pH}$ on the corrosion resistance of titanium and its alloys," Biomaterials, vol. 23, no. 9, pp. 1995-2002, 2002.

[28] A. Robin and J. P. Meirelis, "Influence of fluoride concentration and $\mathrm{pH}$ on corrosion behavior of Ti-6Al-4V and Ti-23Ta alloys in artificial saliva," Materials and Corrosion, vol. 58, no. 3, pp. 173-180, 2007.

[29] A. Robin and J. P. Meirelis, "Influence of fluoride concentration and $\mathrm{pH}$ on corrosion behavior of titanium in artificial saliva," Journal of Applied Electrochemistry, vol. 37, no. 4, pp. 511-517, 2007.

[30] S. Cattarin, I. Frateur, M. Musiani, and B. Tribollet, "Electrodissolution of $\mathrm{p}$-Si in acidic fluoride. Media modeling of the steady state," Journal of the Electrochemical Society, vol. 147, no. 9, pp. 3277-3282, 2000.

[31] J. E. G. Gonzáles and J. C. Mirza-Rosca, "Study of the corrosion behavior of titanium and some of its alloys for biomedical and dental implant applications," Journal of Electroanalytical Chemistry, vol. 471, no. 2, pp. 109-115, 1999.

[32] N. Ibris and J. C. Mirza-Rosca, "EIS study of Ti and its alloys in biological media," Journal of Electroanalytical Chemistry, vol. 526, no. 1-2, pp. 53-62, 2002.

[33] A. Robin and J. P. Meirelis, "EIS study of Ti-23Ta alloy in artificial saliva," Corrosion Engineering, Science and Technology, vol. 44, no. 5, pp. 352-357, 2009.

[34] A. M. Al-Mayouf, A. A. Al-Swayih, N. A. Al-Mobarak, and A. S. Al-Jabab, "Corrosion behavior of a new titanium alloy for dental implant applications in fluoride media," Materials Chemistry and Physics, vol. 86, no. 2-3, pp. 320-329, 2004. 

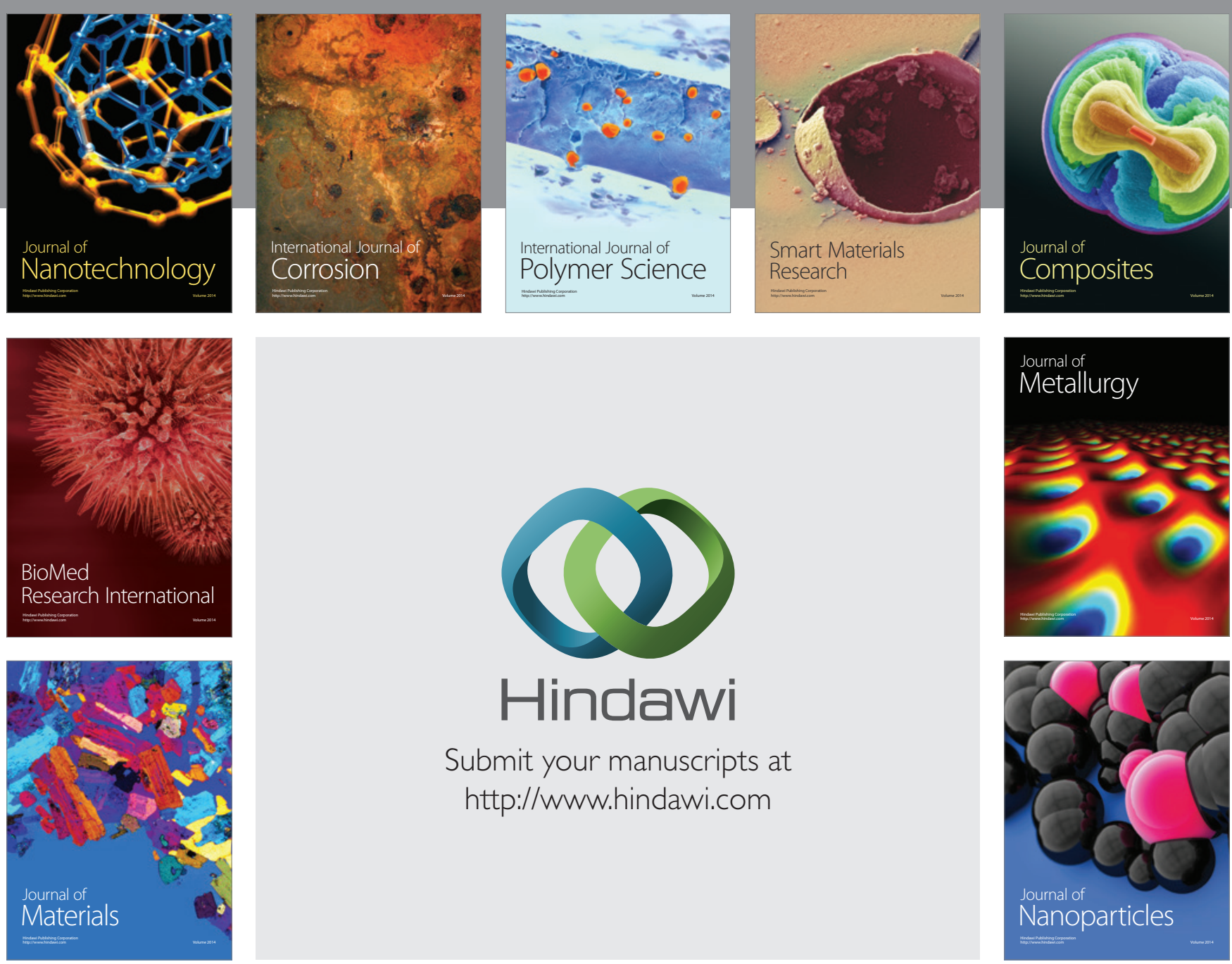

Submit your manuscripts at http://www.hindawi.com
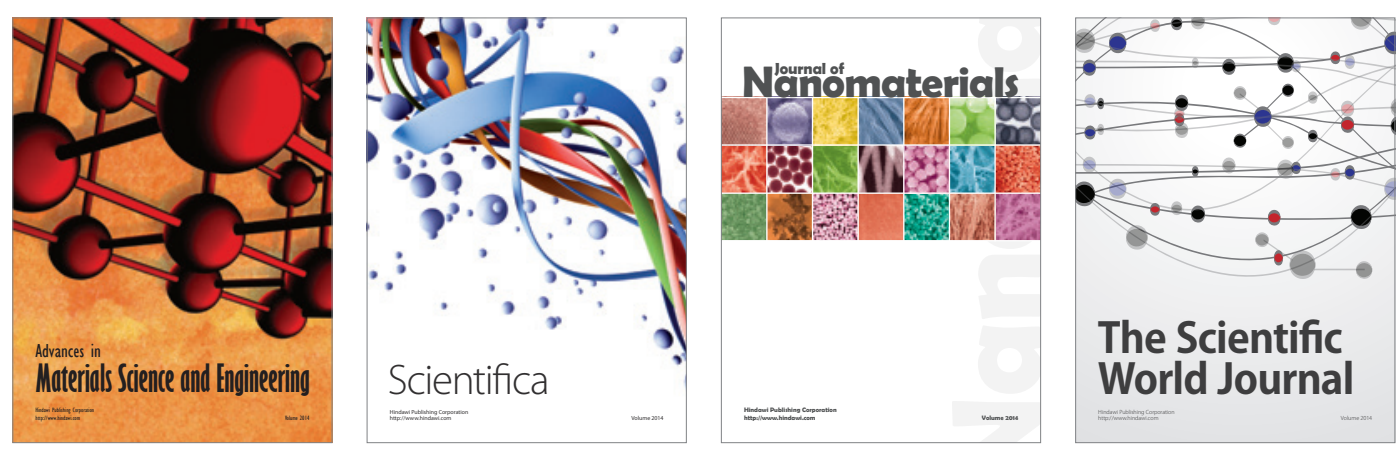

\section{The Scientific World Journal}
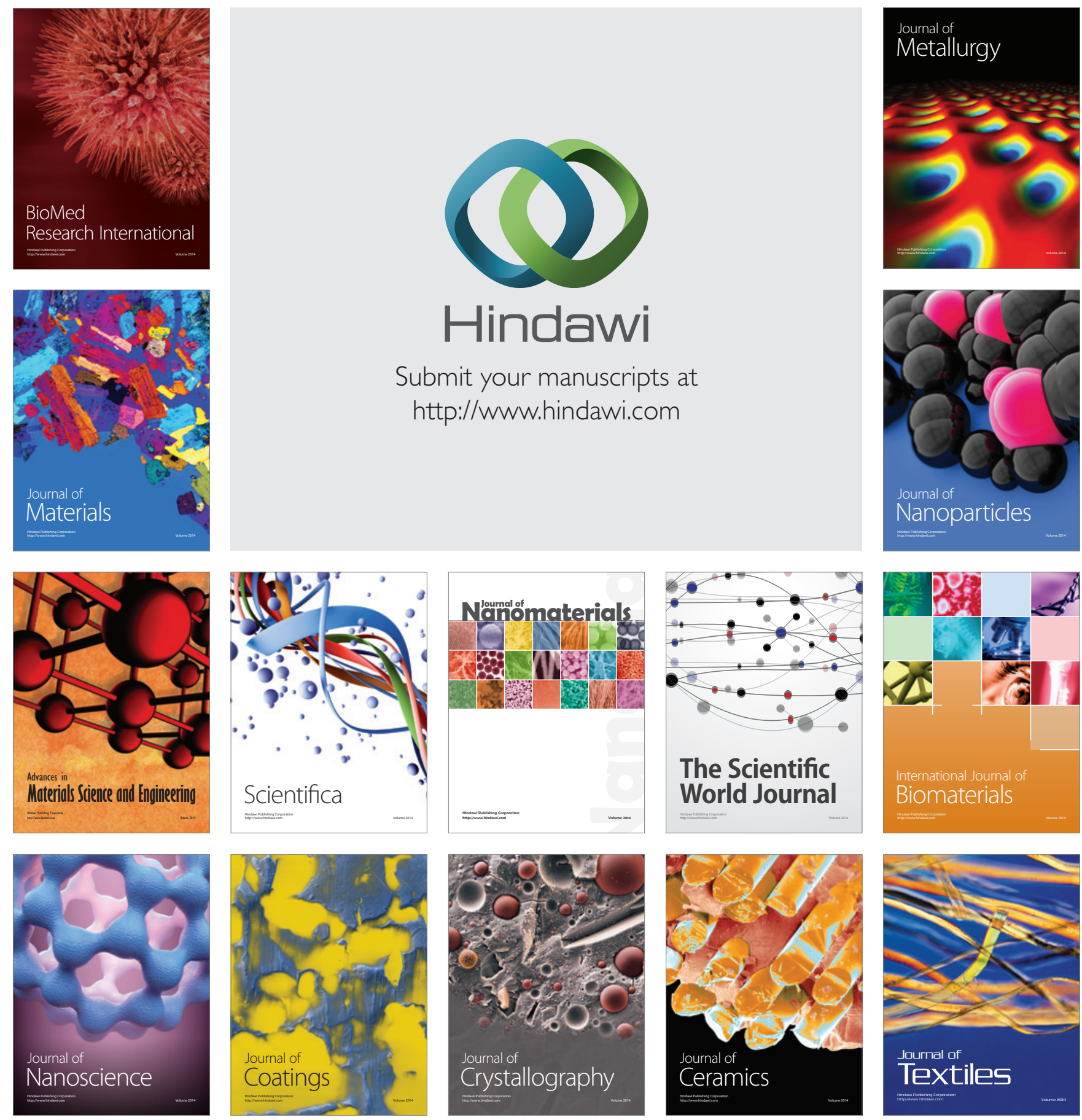